\title{
Ambiances
}

anbiances Environnement sensible, architecture et espace urbain Varia | 2016

\section{Conquering new frontiers in research on store atmospheres: Kinetic and synesthetic qualities}

Conquérir des nouvelles frontières dans la recherche sur les atmosphères des magasins : qualités cinétiques et synesthésiques

\section{Christian Julmi}

\section{(2) OpenEdition}

\section{Journals}

Electronic version

URL: http://journals.openedition.org/ambiances/723

DOI: $10.4000 / a m b i a n c e s .723$

ISSN: 2266-839X

Publisher:

Direction Générale des Patrimoines - DAPA - MCC, UMR 1563 - Ambiances Architectures Urbanités (AAU)

\section{Electronic reference}

Christian Julmi, « Conquering new frontiers in research on store atmospheres: Kinetic and synesthetic qualities », Ambiances [Online], Varia, Online since 15 September 2016, connection on 04 May 2019. URL : http://journals.openedition.org/ambiances/723 ; DOI : 10.4000/ambiances.723

This text was automatically generated on 4 May 2019.

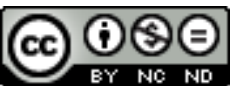

Ambiances is licensed under a Creative Commons Attribution-NonCommercial-NoDerivatives 4.0 International License. 


\title{
Conquering new frontiers in research on store atmospheres: Kinetic and synesthetic qualities
}

\author{
Conquérir des nouvelles frontières dans la recherche sur les atmosphères des \\ magasins : qualités cinétiques et synesthésiques
}

\author{
Christian Julmi
}

\section{Introduction}

1 Since Kotler's (1973) work on atmospherics as a marketing tool, the study of store atmospheres and their effects on the consumer's reaction has become a significant area within marketing research. Kotler understands the atmosphere as "the air surrounding a sphere" or "the quality of the surroundings" (p. 50) and dissects the perception of atmospheres into the main sensory channels sight, sound, scent, and touch. Within these sensory channels, the atmosphere can then be further examined using attributes such as colour, brightness, size, and shapes for the visual dimension. Besides Kotler, the works from Baker (1987) and Bitner (1992) are commonly referred to when operationalizing stimuli. Whereas Baker distinguishes between ambient factors, design factors and social factors, the distinction from Bitner contains ambient conditions, space/function, and signs, symbols, and artefacts. Other, somewhat similar distinctions can be found in Turley \& Milliman (2000), Vilnai-Yavetz, Rafaeli \& Schneider-Yaacov (2005), Grayson \& McNeill (2009), or Berman \& Evans (2013).

2 Empirical investigations of the store atmosphere usually rely upon the StimulusOrganism-Response (S-O-R) model, according to which an (external) stimulus affects an (internal) emotional state leading to a specific behavioural response (Woodworth \& Marquis, 1947; Mehrabian \& Russell, 1974). The starting point for empirical investigations is thus a specific stimulus the customer is faced with. Building on the work of Mehrabian \& Russell (1974), the emotional state can be and often is measured by the three 
independent dimensions pleasure, arousal, and dominance, which is why their model is called Pleasure-Arousal-Dominance (P-A-D) model. Sometimes, the dimension dominance is omitted, because although some findings suggest an independence of the dominance dimension (Russell \& Mehrabian, 1977; Yalch \& Spangenberg, 2000; Yani-de-Soriano \& Foxall, 2006), other findings reject such independence (Russell, 1979; Donovan \& Rossiter, 1982; Donovan, Rossiter, Marcoolyn et al., 1994). Finally, the emotional state leads to a behavioural response. Here, Mehrabian \& Russell distinguish between approach- and avoidance-related behaviour.

3 Whereas the behavioural response is of little interest here, it is the dichotomous distinction between external stimulus and internal state that raises serious problems in conceptualizing the term atmosphere. Kotler distinguishes between the atmosphere and its perception. As mentioned earlier, the atmosphere refers to the quality of the environment as "the air surrounding a sphere". The perceived atmosphere then is literally breathing this air which can be sensed differently by different customers. Hence, the atmosphere seems to belong to the external stimulus, which in turn provokes various individual internal states. From a phenomenological point of view, however, this is problematic. As a holistic quality, the atmosphere can neither be cut off from the environment (the atmosphere is perceived as belonging to the environment) nor from its perceiver (the same environment may evoke different atmospheres depending on the perceiver) without losing its fundamental (i. e., holistic) character (Schmitz, Müllan \& Slaby, 2011; Griffero, 2014a; Griffero, 2014b; Julmi \& Scherm, 2015). When, according to Kotler (1973, p. 50), "one hears a restaurant described as having atmosphere by which is meant that the physical surroundings evoke pleasant feelings", it becomes clear that it makes little sense to talk about an atmosphere without someone being affected by its quality. The atmosphere is neither something that can be exclusively assigned to the external stimulus, nor something that can be exclusively located within an internal state. Whereas the external stimulus can be described and investigated using the S-O-R model, the atmosphere as a whole does not fit into such a model. The object of investigation and the underlying paradigm are therefore incommensurable (Julmi, 2015).

4 Accordingly, it is not surprising that different authors come to different conclusions when it is about to locate the atmosphere either in the external stimulus or in the internal state. Some authors locate the atmosphere within the stimulus (Grossbart, Hampton, Rammohan et al., 1990; Turley \& Milliman, 2000; Tombs \& McColl-Kennedy, 2003; Yani-de-Soriano \& Foxall, 2006; Rayburn \& Voss, 2013). Babin \& Attaway (2000, p. 91) even speak about the "physical atmosphere". Other authors, however, assume that the atmosphere is a psychological variable (Buckley, 1987; Ghosh, 1990; Berman \& Evans, 2013). Following this latter point of view, Foxall, Goldsmith \& Brown (1998, p. 201) provide an alternative interpretation of Kotlers work:

As Kotler points out, consumers purchase a total product, consisting not simply of the physical item bought but the packaging, aftersales deal, advertising, image, and -most importantly-the atmosphere of the place in which the transaction takes place. Atmospherics do not, therefore, refer to the objective physical and social factors that constitute store image [...] but to the subjective feelings these factors engender in consumers.

5 The consequence of the obvious mismatch between atmosphere as the object of investigation and the (explicitly or implicitly) underlying S-O-R model is the detectable avoidance of the term "atmosphere" within the existing literature (see, for example, the review from Turley \& Milliman, 2000). Whereas the term is frequently considered in 
headlines and introductions, it is rather ignored when things are getting more concrete. Symptomatically, Kotler, Keller, Brady et al. (2009, p. 679) start their section on "Service atmosphere" with the remark that "Atmosphere is a major marketing element" without any further use of the term throughout the whole chapter. If the term is nevertheless considered in a more technical manner, things get confusing. Donovan \& Rossiter (1982, p. 35) write that "store atmosphere effects are basically emotional states", indicating that the atmosphere is an external stimulus having an effect on the internal state. On the other hand, they claim that "physical variables are antecedents of store atmosphere rather than alternatives to it", indicating that the atmosphere is an internal state. As the authors explicitly follow the S-O-R model, there are no alternatives other than that, although the text somehow rather suggests that the atmosphere is something in between external stimulus and internal state-like Böhme (1993, p. 114) puts it with his notion that "this in-between, by means of which environmental qualities and states are related, is atmosphere".

6 The problems identified here are by no means of theoretical nature only. If it is not clear, whether the atmosphere belongs to the external stimulus or the internal state, then it is also unclear how it should be measured empirically, since external and internal variables are quite different regarding the S-O-R model. The atmosphere manifests itself as a bridge between subject and object, as a glue that sticks subject and object together. Although phenomenologically evident, an understanding of atmospheres based on qualities bridging subject and object-so-called bridging qualities-has yet to be developed within marketing theory. The phenomenological work of German philosopher Hermann Schmitz could well serve as a starting point here, as it is these kinds of bridging qualities that are central to Schmitz' understanding of atmospheres. In order to further pursue this idea, the related concepts in the philosophy of Schmitz have to be introduced first.

\section{Kinetic and synesthetic qualities as bridging qualities}

7 Schmitz is acknowledged as the founder of new phenomenology (or neophenomenology), a phenomenological movement developed to regain "a sensibility for the nuanced realities of lived experience" (Schmitz, Müllan \& Slaby, 2011, p. 241). Although Schmitz developed the greater part of his new phenomenology in a book series of ten volumes from 1964 to 1980, his work is still being elaborated and advanced in more recent publications (e. g., Schmitz, 2014, 2015). In Germany, "Schmitz has influenced a new generation of philosophers and is becoming more frequently cited by English speaking scholars" (Grant, 2013, p. 16). Outside of marketing research, the significance of Schmitz' work on atmospheres has been acknowledged and applied in different areas such as aesthetics (Böhme, 1993; Griffero, 2014a; Griffero, 2014b; Rauh, 2014), medicine ( Langewitz, 2007), architecture (Löw, 2008; Hasse, 2011, 2014; Grant, 2013; Pallasmaa, 2014 ), law (Philippopoulos-Mihalopoulos, 2013), emotion theory (Slaby, 2014), creativity research (Julmi \& Scherm, 2015), archaeology (Sørensen, 2015), and ethnomusicology ( McGraw, 2016).

Looking at the research field of atmospheres in general, it is Schmitz who puts particular emphasis on the significance of bridging qualities for the constitution of atmospheres. According to Schmitz (1969, 1974, 1977, 1978, 1992, 2009, 2011, 2014, 2016), atmospheres are spatially poured out emotions that are objectively present in the space. Although objectively present, atmospheres are subjectively felt and perceived holistically on the 
own felt body. It is important to note here that Schmitz' understanding of subjectivity and objectivity is non-dualistic, meaning that subjectivity and objectivity are not at all assumed as mutually exclusive. Following Schmitz, it is not the subjects and objects that are subjective and objective in the first place. Rather, subjectivity and objectivity refer to facts (or, more broadly, to state of affairs). A fact is objective when it can be stated by anyone who possesses sufficient information to do so. In contrast, a fact is considered as subjective when it can only be stated by the person who is affectively involved. If, for example, the atmosphere of a specific place is considered as scary, this represents an objective fact. But only if someone is affectively involved in such an atmosphere ("I" am the one who is actually scared), the atmosphere becomes a subjective fact as well. The subjective fact in this example is richer than the objective fact, because it contains the nuance of subjectivity that the referring objective fact lacks. There can be many (objective) atmospheres within a place, but someone can only (subjectively) be affected by one atmosphere at a time. By which atmosphere someone is affected, depends, for example, on his attention and intention (Scherm \& Julmi, 2012). For Schmitz, objectivity means intersubjectivity, so the objectivity of atmospheres is always bound to a shared common sense. If no one is able to be scared, there are no scary atmospheres per se. Because objectivity and subjectivity refer to facts instead of objects and subjects, an objective atmosphere is by no means independent from the subject (which would indicate a mutual exclusiveness). The interplay between the objective (or intersubjective) presence of atmospheres in space and the felt body rests upon bridging qualities. Bridging qualities can be defined with Schmitz as qualities that are present in the objective space (which is not the physical space), but can also be found in the subjective felt body. Schmitz differentiates between two types of bridging qualities: kinetic and synesthetic qualities (the latter not to be confused with synesthesia).

Kinetic qualities are suggestions or omens of motions, which can emanate from executed as well as from latent motions. Examples for kinetic qualities are a glare, a pointed finger that stabs the person pointed at like a dagger, an eye-stinging smell, the branches of a weeping willow, the rhythm of a piece of music or the affordance of a door knob (Gibson, 1977). Another example is the dynamic design of a sports car: even if the car is not moving, its shape corporeally suggests a dynamic motion and therefore is perceived as dynamic. Haverkamp (2013) speaks about the concept of kinetic design in this context. Kinetic qualities are organized through the shape of gestalts and effectively affect the felt body. An artefact like a huge Christmas tree being located immediately behind a small entrance, for example, suggests a motion from the bottom up which manifests itself in a corresponding movement of one's head (Großheim, Kluck \& Nörenberg, 2015). The kinetic quality of fast music as a suggestion of motion makes people drink faster (McElrea \& Standing, 1992). The complexity of kinetic qualities can be illustrated with a casual glance, which can be a gesture of begging, seduction, devotion or irony.

Synesthetic qualities are qualities that go beyond the allocation to individual genres of perception, such as colours, temperatures, noise or light. A colour is not only perceived as red or brown, but also as bright (light) or warm (temperature). Sounds are associated as heavy, dense or hard (mass), but also as dark (light), cold (temperature) or fast (velocity). In general, synesthetic characters stand out due to plus qualities such as bright, warm, fast, loud and minus qualities such as dark, cold, calm, quiet (and a neutral zone between them). 
11 Kinetic and synesthetic qualities are often intertwined. The stimulating environment of a store, for example, relates to various affordances as kinetic qualities as well as to weightlessness (mass) or flowing rhythms (sound) as synesthetic qualities. Both types of bridging qualities cannot be measured physically but phenomenologically affect the felt body. Although Kotler (1973) shared the opinion that the sense of taste is not directly relevant for atmospheres, kinetic and synesthetic qualities are present in the sense of taste as well. The atmospheric quality of a wine, for example, is assessed both with kinetic qualities such as the tingling or biting aroma and synesthetic qualities such as a soft or heavy taste (Julmi \& Scherm, 2015). Accordingly, Spence, Puccinelli, Grewal et al. (2014, p. 479) state that the "subjectivity of taste creates an inherent complexity for its use in atmospherics".

\section{Kinetic and synesthetic qualities within marketing Research}

So far, kinetic and synesthetic qualities have been largely neglected in the research field of store atmospheres so far. One study explicitly stressing the importance of kinetic qualities regarding the perception of store environments stems from Bonnin \& Goudey (2012). The authors define kinetic quality as "the appreciation of the store with regard to the movements and gestures that can be performed during the shopping trip" (p. 637). It is the "configuration of the store, its layout and more broadly its design" that "channel the movements and gestures of shoppers and probably influence the kinetic quality of the store" (p. 637). Although Bonnin \& Goudey do not refer to the phenomenological work of Schmitz, their idea of kinetic qualities draws from contiguous areas such as practice theory, ethnography and phenomenology. It is therefore not surprising that their understanding is quite consistent with the outlined conception of kinetic qualities. Their conclusion that "Music and visual esthetics, although not channeling directly movements and gestures influence the perception of the kinetic quality of the store" (p. 641) fits well within the concept of kinetic qualities outlined here. Nevertheless, Bonnin \& Goudey see the kinetic quality as different from the affective or atmospheric quality (but being analytically located at the same level), although it is suggested here that the kinetic quality is an atmospheric quality (or a subset of atmospheric qualities) as it literally affects the felt body.

13 The relevance of synesthetic characters in the context of atmospheres within marketing research has been highlighted by Sharma \& Stafford (2000), Joy \& Sherry, JR. (2003), Biehl-Missal \& Saren (2012), Biehl-Missal (2013), and Haverkamp (2013). For example, Biehl-Missal \& Saren (2012, p. 173) state: "Because of its synesthetic character, which is informed by different senses, we are able to describe material's warmth or coolness in an atmospheric sense." In their work, Biehl-Missal \& Saren (2012) and Biehl-Missal (2013) draw on the aesthetic theory of Böhme $(1993,1995,2003,2006)$. Böhme himself is greatly influenced by Schmitz (Grant, 2013; Julmi, 2015) and also highlights the atmospheric relevance of kinetic and synesthetic qualities (Böhme, 1995, 2006, 2013). Beyond considering synesthetic qualities as such, the concept of multisensory store atmospherics introduced by Spence, Puccinelli, Grewal et al. (2014) perhaps comes closest to the study of synesthetic characters regarding store atmospheres, although the interaction of different senses is still not the same as considering one quality (e. g., warm) being relevant for different senses. The importance of congruency for multisensory store 
atmospherics seems nevertheless relevant for dealing with synesthetic characters as well. If, for instance, someone aims to create a cosy atmosphere, he rather avoids elements inducing coldness in a synesthetic sense. Correspondingly, the authors acknowledge: "An area of growing research interest pertains to the synesthetic (and surprising) correspondences that exist between the senses" (p. 481).

In other, yet highly relevant research fields, the examination of synesthetic characters has recently attracted attention under the label of crossmodal correspondence, for example the crossmodal correspondence between olfaction and touch (Demattè, Sanabria, Sugarman et al., 2006), odors and music (Crisinel \& Spence, 2012), odors and shape (Hanson-Vaux, Crisinel \& Spence, 2013) or taste and music (Crisinel, Cosser, King et al., 2012). Other terms to refer to similar phenomena include synaesthetic correspondences, synaesthetic associations, crossmodal equivalences, crossmodal similarities, and natural crossmodal mappings (Spence, 2011). The direction of research clearly indicates an increasing interest in studying synesthetic characters.

However, when the rejection of the S-O-R model is taken seriously, kinetic and synesthetic qualities cannot be treated as something being independent of or prior to individual experience. Although objective in the given sense, kinetic and synesthetic qualities are only accessible through a person's subjective perspective and experience. The same setting within or outside a store may atmospherically affect the customers in different ways. Jewellery stores with imposing doors, for example, create an exclusive atmosphere, encouraging those seeking for exclusiveness to enter whereas simultaneously discouraging nonserious shoppers (Biehl-Missal \& Vom Lehn, 2015). Depending on the situation of the shopper, the same setting evokes (attractive) centripetal kinetic qualities and warm synesthetic qualities in the first case, and (repulsive) centrifugal kinetic qualities and cold synesthetic qualities in the second case. Thus, the purposefully arranged kinetic qualities of the store exterior preselect the customers even before entering the store, demonstrating their great potential for marketing research. To tap this potential, the study of kinetic and synesthetic qualities has to consider the customer's situations.

\section{Atmospheres and situations}

Within the new phenomenology, the concept of situation is a key concept closely connected to the concept of atmosphere. For Schmitz, people are always embedded in situations. He formally defines a situation through three attributes. Firstly, situations are uniform, that is, they are characterized by coherence in themselves and by external detachment. Secondly, situations cohere through a meaningfulness that consists of significances. Significances are state of affairs, programs or problems. A state of affairs indicates that something is (e. g., the price segment of a store or brand); a program means that something should be or is desired (e. g., the customers' needs); a problem refers to the question of whether something is (e.g., whether something is affordable). Significances may be objective or subjective facts. Thirdly, the meaningfulness of a situation is internally diffuse. This means that individual significances have to be neither individually countable nor separable from each other. Individual significances may stand in contradiction to each other without threatening the wholeness of the situation. situations through which the personal situation obtains a social background. Schmitz 
differentiates between two types of shared situations: actual and conventional situations. Whereas actual situations are formed by the actual moment and can easily be tracked from moment to moment (e. g., the situation of a conversation), conventional situations consist of more segmented, social conventions. Social conventions determine what is expected to be done or not to be done (norms), what someone is allowed to do without receiving a sanction and what someone is expected to wish for. It is only due to the fact that the conventions are given as an internally diffuse meaningfulness that its participants are able to rely on them in a naïve, pre-reflective way. Actual situations can turn into conventional situations, for example when few people, who enjoy a unique shopping experience ultimately start a new trend by forming and establishing new social conventions regarding what the customer's expected experiences are expected to be like. The more conventional a situation gets, the less it is open to new influences and the less it allows deviations of (expected) behaviour (Julmi, 2015).

As Schmitz points out, situations in general are permeated with atmospheres giving the situation its specific and emotional undertone. Whether a store atmosphere is perceived as exciting or depressing depends on the situation of the customer (or a group of customers sharing the same situation). When customers are in a situation where their needs can potentially be satisfied due to affordable prices, the atmosphere may be perceived as exciting (coming along with uplifting kinetic and light synesthetic qualities), whereas in the opposite case, the atmosphere may be perceived as depressive (coming along with oppressing kinetic and heavy synesthetic qualities). In the end, there are at least as many different atmospheres within a store environment as there are customers in different situations.

Importantly, atmospheres do not only underlie, but also shape situations; they have the potential to "influence our perception of reality, to the point of subtly shaping beliefs, norms and cultural values" (Gagliardi, 2006, p. 706). Music, for example, is an atmosphere affecting people through kinetic (e.g., the suggested movement of the rhythm) and synesthetic qualities (e. g., warm or cold sounds). Stimulating rhythms with a warm melody may evoke an exciting atmosphere, eventually pushing the customers towards a situation in which the programs indicate that buying products is something desired. Although the atmosphere is not itself a situation, it impregnates the situation people find themselves in. Even putting headphones on can shed an entirely different light on reality, on what seems desirable or tedious (Schouten, 2007). On this view, atmospheres have the power to evoke situations. The conventional situation of Christmas, for example, can be evoked through the conscious use of Christmas-like kinetic and synesthetic qualities:

The scents of pine, cinnamon and mulled cider join with the sounds of carolers, traditional hymns and pop holiday tunes to create the Christmas holiday season in the minds of many. In attempts to attract Christmas shoppers to their stores, retailers often implement such mainstay environmental cues to create pleasant and enticing atmospheres that evoke the spirit of the holiday season. (Spangenberg, Grohmann \& Sprott, 2005, p. 1583)

Comparing actual and conventional situations, one may differentiate between aesthetic atmospheres (in actual situations) and anaesthetic (or kitschy) atmospheres (in conventional situations). Whereas aesthetics "is the sensibilities activated to help the human observe", anaesthetics "is the means whereby the sensory faculties are blunted" (Strati, 1999, p. 81). Aesthetic atmospheres go beyond (or break with) conventions, turning the perceiver's attention to unique, unforeseen bridging qualities, stimulating her experience in a new, creative way. Anaesthetic atmospheres, on the other hand, have 
their origins rather in the expectations of the perceiver than in the environment, meaning that any deviation of the (actual) atmosphere from the expected atmosphere will be judged as dissonant. If the expectations are met and people get exactly what they want, the atmosphere is like a sedative anaesthetising their experience (Marquard, 1989). A museum would be an example for an environment inducing aesthetic atmospheres stimulating the senses (Joy \& Sherry, JR., 2003; Biehl-Missal \& Vom Lehn, 2015), although the environment of museums of course also relies on anaesthetic bridging qualities. For kinetic qualities, Goulding (2000, p. 274) notes that it is essential in museums "not to let the experience start with frustration, anxiety and disorientation. Clear and easy to follow maps will allow the visitor to focus attention on the exhibit and enable the planning of a particular route". In contrast, the emphasis of a Christmas market rather lies on meeting expectations about how Christmas has atmospherically to be like, although aesthetic bridging qualities to create unique experiences may play here a role as well. In general, the emphasis may be more on aesthetic or anaesthetic atmospheres, but in the end both are necessary for most store environments, with the former creating unique shopping experiences and the latter providing context, orientation and organization.

21 On the whole, the situations of the visitors have to be taken into account, but can also be influenced by the atmosphere of the environment. Therefore, the atmospheric design of store environments becomes an intricate endeavour, balancing the need for considering the customers' situations and expectations with the possibilities to shape actual situations through aesthetic kinetic and synesthetic qualities.

\section{Implications for research on store atmospheres}

The outlined approach on store atmospheres has several implications for research. The rejection of the S-O-R model goes along with a call for approaching store atmospheres with consideration of the specific situations of the customers. Shopping within a store is far from being a distinct and universal shared situation with a distinct and universal (shared) store atmosphere. Even the specific circumstances within the fitting room of a store induce its own situation. Ganetz (1995, p. 86-87) describes the fitting room as an area in which "the crowdedness and consequent intimate atmosphere seems to develop an extra intimacy and psychic closeness, especially since everyone in the fitting room is half undressed".

Accordingly, the atmosphere within a store cannot be studied without considering the given situation. The perception of kinetic and synesthetic qualities are induced (or at least moderated) by the specific situation of the customer. Therefore, specifying the given or intended situation (or, more precisely, the given or intended state of affairs, programmes, and problems) is a necessary first step for any investigation of store atmospheres. As the possible range of situations is manifold rather than countable, typologies of relevant situations have to be built for proper analysis. Here, insights from practice theory, which is commensurable with new phenomenology (Rappe, 2005), may be of help in fragmenting situations. The given definition of a situation seems consistent, for example, with the definition of a practice from Reckwitz (2002, p. 249), according to whom a practice "is a routinised type of behaviour which consists of several elements, interconnected to one another: forms of bodily activities, forms of mental activities, 'things' and their use, a background knowledge in the form of understanding, know-how, states of emotion and motivational knowledge". Thus, shopping situations mostly refer to 
specific shopping practices (or to what Gregson, Crewe \& Brooks, 2002, call modes of shopping), which is also consistent with the finding that the experience of (emotional) atmospheres is closely linked to shopping practices (Colls, 2004).

An example of a shopping practice typology is given by Kazig $(2012,2013)$ who investigates the link between specific shopping practices and shopping atmospheres. Based on the explorative analysis of problem-centered interviews, Kazig identifies and describes three distinct shopping practices, each inducing its own type of atmosphere: practices for strolling, practices for rummaging, and practices with a cultural resonance. As Kazig shows, each practice is associated with different kinds of atmospheric qualities. Whereas, for example, the presence of sales staff evokes (repulsive) centrifugal kinetic qualities and harsh synesthetic qualities competing with the experience of an unhindered rummaging, such a presence is desired and synesthetically perceived as warm and familiar when customers are in a resonating environment. An atmosphere of cultural resonance emerges, for example, when the customer identifies herself with the dress style of the sales staff. Although Kazig does not explicitly use kinetic and synesthetic qualities as basal atmospheric categories, the use of such categories could probably enrich the analysis and codification of qualitative empirical data. If subjects are asked to describe their personal in-store atmosphere, given descriptions can be analysed identifying kinetic and synesthetic metaphors as these are frequently used in daily speech (Großheim, Kluck \& Nörenberg, 2015). People naturally speak about overall atmospheres being cold or warm, heavy or weightless, bright or dark (synesthetic qualities), suppressive or uplifting, narrowing or widening, attractive or repulsive, inspiring or inexpressive (kinetic qualities). Analogously, state of affairs, programmes, and problems may serve as basal categories for building typologies of situations or practices (Hasse, 2002). However, such an analysis of situations is limited to conventional situations, because actual situations (and aesthetic atmospheres) are always exceptional and unique. As there is no typical actual situation, such situations can only be studied in situ. When a store environment is built to exceed the customer's expectations, the potential contribution of empirical research is generally low.

\section{Conclusion}

Research on the influence of store environments on customer's shopping behaviour can pursue a micro or a macro level of perspective which can be described as the molecular and the molar perspective (Bonnin \& Goudey, 2012). The molecular perspective focuses on smaller units and typically studies the impact of single stimuli to the customer perception of the store environment. In contrast, the molar perspective gives priority to the holistic perception of the store environment. Whereas early research in this field has clearly favoured a molecular perspective based on the S-O-R-model, recent work puts stronger emphasis on holistic approaches underlying a molar perspective (Ballantine, Jack \& Parsons, 2010; Bonnin \& Goudey, 2012; Rayburn \& Voss, 2013; Petermans, Janssens \& van Cleempoel, 2013; Ballantine, Parsons \& Comesky, 2015). As atmospheres cannot be located within a dichotomy of object (or stimulus) and subject (or organism), the S-O-R model is generally not suitable for the study of atmospheres. Thus, any molecular approach to the study of atmospheres has to be rejected according to the concerns outlined earlier. If an atmosphere is reduced to single stimuli, it can no longer be called an atmosphere. This does not mean, however, that examining the effects of specific 
stimuli on consumer's behaviour is itself in question. The point made here is rather that in such cases it is not appropriate using atmosphere as an umbrella term. The study of atmospheres strictly requires a molar perspective.

Since kinetic and synesthetic qualities are essential to atmospheres, its irreducibility to single stimuli is not only a feature of atmospheres, but also reflects its very nature. Although objectively present in space, bridging qualities are quite distinct from physical stimuli and can therefore not be measured physically. The synesthetic quality of silence, for example, can be a very intense quality, although, from a physical point of view, silence is characterized by the absence of sound. This is equally true for kinetic qualities, because suggestions of motions can as well be inherent in motionless environments or shapes. Synesthetic and kinetic qualities can neither be separated from the environment nor from the perceiver. Beyond, they cannot be separated from the situation of the customers within this environment, so the study of store atmospheres is necessarily also a study of the customer's conventional situations. If a store environment is built to evoke aesthetic atmospheres stemming from actual situations, such experiences can only be studied in situ.

Hence, atmospheres cannot be depicted within a distinct cause-and-effect relationship model and have to be explored in a holistic, interpretative and situative manner.

In summary, the approach presented here contributes to the research of store atmospheres in two ways. First, molecular perspectives on atmospheres are criticized as inappropriate as store atmospheres cannot be understood on a sense-by-sense basis ( Spence, Puccinelli, Grewal et al., 2014). Accordingly, research designs pursuing molar perspectives on store atmospheres that consider the situative embeddedness of atmospheres are encouraged. Second, the concept of bridging qualities with the two types of kinetic and synesthetic qualities is introduced to marketing theory as a promising direction for future research. Recent research indicates the relevance of both types of bridging qualities, albeit none of the works systematically considered both kinetic and synesthetic qualities so far-a route that should be worth following in the future.

\section{BIBLIOGRAPHY}

Babin, Barry J. \& Attaway, Jill S. 2000. Atmospheric affect as a tool for creating value and gaining share of customer. Journal of Business Research. vol. 49, n², p. 91-99.

Baker, Julie. 1987. The role of the environment in marketing services: The consumer perspective. In: John A. Czepiel, Carole Congram \& James Shanahan (eds.). The services challenge: Integrating for competitive advantage. Chicago: American Marketing Association, p. 79-89.

Ballantine, Paul W.; Jack, Richard \& Parsons, Andrew G. 2010. Atmospheric cues and their effect on the hedonic retail experience. International Journal of Retail \& Distribution Management. vol. 38, $\mathrm{n}$ 8, p. 641-653. 
Ballantine, Paul W.; Parsons, Andrew G. \& Comesky, Katrina. 2015. A conceptual model of the holistic effects of atmospheric cues in fashion retailing. International Journal of Retail \& Distribution Management. vol. 43, $n^{\circ}$ 6, p. 503-517.

Berman, Barry \& Evans, Joel R. 2013 [1979]. Retail management. A strategic approach. $12^{\mathrm{e}}$ édition. Boston, Columbus, Indianapolis, New York, San Francisco, Upper Saddle River: Pearson.

Biehl-Missal, Brigitte. 2013. The atmosphere of the image: An aesthetic concept for visual analysis. Consumption Markets \& Culture. vol. 16, $\mathrm{n}^{\circ}$ 4, p. 356-367.

Biehl-Missal, Brigitte \& Saren, Michael. 2012. Atmospheres of seduction: A critique of aesthetic marketing practices. Journal of Macromarketing. vol. 32, $\mathrm{n}^{\circ}$ 2, p. 168-180.

Biehl-Missal, Brigitte \& Vom Lehn, Dirk. 2015. Aesthetics and atmosphere in museums: A critical marketing perspective. In: Michelle Henning (eds.). The international handbooks of museum studies. vol. 3: Museum media. Chichester: Wiley-Blackwell, p. 235-258.

Bitner, Mary J. 1992. Servicescapes: The impact of physical surroundings on customers and employees. Journal of Marketing. vol. 56, n², p. 57-71.

Böhme, Gernot. 1993. Atmosphere as the fundamental concepts of new aesthetics. Thesis Eleven. vol. $36, \mathrm{n}^{\circ} 1$, p. 113-126.

Böhme, Gernot. 1995. Atmosphäre. Essays zur neuen Ästhetik. Frankfurt a. M.: Suhrkamp.

Böhme, Gernot. 2003. Contribution to the critique of the aesthetic economy. Thesis Eleven. vol. 73, $\mathrm{n}^{\circ}$ 1, p. 71-82.

Böhme, Gernot. 2006. Architektur und Atmosphäre. München: Wilhelm Fink Verlag.

Böhme, Gernot. 2013. Synaesthesiae within the scope of a phenomenology of perception.

Wolkenkuckucksheim. vol. 31, p. 23-33.

Bonnin, Gaël \& Goudey, Alain. 2012. The kinetic quality of store design: An exploration of its influence on shopping experience. Journal of Retailing and Consumer Services. vol. 19, $\mathrm{n}^{\circ} 6$, p. 637-643.

Buckley, Patrick G. 1987. The internal atmosphere of a retail store. Advances in Consumer Research. vol. $14, \mathrm{n}^{\circ} 1$, p. 568.

Colls, Rachel. 2004. 'Looking alright, feeling alright'. Emotions, sizing and the geographies of women's experiences of clothing consumption. Social \& Cultural Geography. vol. 5, n 4, p. 583-596

Crisinel, Anne-Sylvie; Cosser, Stefan; King, Scott; Jones, Russ; Petrie, James \& Spence, Charles. 2012. A bittersweet symphony: systematically modulating the taste of food by changing the sonic properties of the soundtrack playing in the background. Food Quality and Preference. vol. $24, \mathrm{n}^{\circ} 1$, p. 201-204.

Crisinel, Anne-Sylvie \& Spence, Charles. 2012. A fruity note: Crossmodal associations between musical notes. Chemical Senses. vol. 37, n 2, p. 151-158.

Demattè, M. Luisa;; Sanabria, Daniel;; Sugarman, Rachel \& Spence, Charles. 2006. Cross-modal interactions between olfaction and touch. Chemical Senses. vol. 31, $n^{\circ} 4$, p. 291-300.

Donovan, Robert J. \& Rossiter, John R. 1982. Store atmosphere: An environmental psychology approach. Journal of Retailing. vol. 58, n 1, p. 34-57.

Donovan, Robert J.; Rossiter, John R.; Marcoolyn, Gilian \& Nesdale, Andrew. 1994. Store atmosphere and purchasing behavior. Journal of Retailing. vol. 70, n 3, p. 283-294. 
Foxall, Gordon R.; Goldsmith, Ronald E. \& Brown, Stephen. 1998 [1994]. Consumer psychology for marketing. $2^{\mathrm{e}}$ édition. London: Thomson.

Gagliardi, Pasquale. 2006. Exploring the aesthetic side of organizational life. In: Stewart R. Clegg, Cynthia Hardy, Thomas B. Lawrence \& Walter R. Nord (eds.). The SAGE Handbook of organization studies. $2^{\mathrm{e}}$ édition. London, Thousand Oaks, New Delhi: SAGE Publications, p. 701-724.

Ganetz, Hillevi. 1995. The shop, the home and femininity as a masquerade. In: Johan Fornäs \& Göran Bolin (eds.). Youth culture in late modernity. London: Sage, p. 72-99.

Ghosh, Avijit. 1990. Retail Management. Chicago: The Dryden Press.

Gibson, James J. 1977. The theory of affordances. In: Robert Shaw \& John Bransford (eds.). Perceiving, acting, and knowing: Toward an ecological psychology. Hillsdale: Erlbaum, p. 67-82.

Goulding, Christina. 2000. The museum environment and the visitor experience. European Journal of Marketing. vol. 34, $n^{\circ}$ 3/4, p. 261-278.

Grant, Stuart. 2013. Performing on aesthetics of atmosphere. Aesthetics. vol. 23, n 1, p. 12-32. Grayson, Rollo A. S. \& McNeill, Lisa S. 2009. Using atmospheric elements in service retailing: Understanding the bar environment. Journal of Services Marketing. vol. 23, nº 7, p. 517-527. Gregson, Nicky; Crewe, Louise \& Brooks, Kate. 2002. Shopping, space, and practice. Environment and Planning D: Society and Space. vol. 20, $n^{\circ}$ 5, p. 597-617.

Griffero, Tonino. 2014a. Atmospheres: Aesthetics of emotional space. Farnham: Ashgate.

Griffero, Tonino. 2014b. Who's afraid of atmospheres (and of their authority)? Lebenswelt. Aesthetics and Philosophy of Experience. vol. 4, p. 193-213.

Grossbart, Sanford; Hampton, Ronald; Rammohan, B. \& Lapidus, Richard S. 1990. Environmental dispositions and customer response to store atmospherics. Journal of Business Research. vol. 21, $\mathrm{n}$ • 3, p. 225-241.

Großheim, Michael; Kluck, Steffen \& Nörenberg, Henning. 2015. Kollektive Lebensgefühle. Zur Phänomenologie von Gemeinschaften. Rostock: Universität Rostock, Institut für Philosophie.

Hanson-Vaux, Grant; Crisinel, Anne-Sylvie \& Spence, Charles. 2013. Smelling shapes: Crossmodal correspondences between odors and shapes. Chemical Senses. vol. 38, $\mathrm{n}^{\circ} 2$, p. 161-166.

Hasse, Jürgen. 2002. Die Atmosphäre einer Straße. Die Drosselgasse in Rüdesheim am Rhein. In: Jürgen Hasse (eds.). Subjektivität in der Stadtforschung. Frankfurt am Main: Institut für Didaktik der Geographie (Natur - Raum - Gesellschaft, 3), p. 61-113.

Hasse, Jürgen. 2011. Emotions in an urban environment: Embellishing the cities from the perspective of the humanities. In: Heiko Schmid, Wolf-Dietrich Sahr \& John Urry (eds.). Cities and fascination. Beyond the surplus of meaning. Farnham: Ashgate, p. 49-74.

Hasse, Jürgen. 2014. Atmospheres as expression of medial power. Understanding atmospheres in urban governance and under self-guidance. Lebenswelt. Aesthetics and Philosophy of Experience. vol. 4, p. 214-229.

Haverkamp, Michael. 2013. Synesthetic design: Handbook for a multi-sensory approach. Basel: Birkhäuser.

Joy, Annamma \& Sherry, John F., JR. 2003. Speaking of art as embodied imagination: A multisensory approach to understanding aesthetic experience. Journal of Consumer Research. vol. $30, \mathrm{n}^{\circ} 2$, p. 259-282. 
Julmi, Christian. 2015. Atmosphären in Organisationen. Wie Gefühle das Zusammenleben in Organisationen beherrschen. Bochum: Projekt Verlag.

Julmi, Christian \& Scherm, Ewald. 2015. The domain-specificity of creativity: Insights from new phenomenology. Creativity Research Journal. vol. 27, n² 2, p. 151-159.

Kazig, Rainer. 2012. Resource rather than seduction. A praxeological conception of shopping atmospheres. In: Jean-Paul Thibaud \& Daniel Siret (eds.). Ambiances in action / Ambiances en acte(s). International Congress on Ambiances, Montreal, Sep 2012. Montreal: International Ambiances Network, p. 63-68.

Kazig, Rainer. 2013. Einkaufsatmosphären. Eine alltagsästhetische Konzeption. In: Heiko Schmid \& Karsten Gäbler (eds.). Perspektiven sozialwissenschaftlicher Konsumforschung. Stuttgart: Franz Steiner Verlag, p. 217-232.

Kotler, Philip. 1973. Atmospherics as a marketing tool. Journal of Retailing. vol. 49, n 4, p. 48-64.

Kotler, Philip; Keller, Kevin L.; Brady, Mairead; Goodman, Malcolm \& Hansen, Torben. 2009. Marketing management. Harlow: Pearson.

Langewitz, Wolf. 2007. Beyond content analysis and non-verbal behaviour - What about atmosphere? A phenomenological approach. Patient Education and Counseling. vol. 53, p. 319-323.

Löw, Martina. 2008. The constitution of space. The structuration of spaces through the simultaneity of effect and perception. European Journal of Social Theory. vol. 11, n 1, p. 25-49.

Marquard, Odo. 1989. Aesthetica und Anaesthetica. Philosophische Überlegungen.

Paderborn: Schöningh.

McElrea, Heather \& Standing, Lionel. 1992. Fast music causes fast drinking. Perceptual \& Motor Skills. vol. $75, \mathrm{n}^{\circ} 2$, p. 362.

McGraw. 2016. Atmosphere as a concept for Ethnomusicology. Comparing the gamelatron and gamelan. Ethnomusicology. vol. 60, n 1, p. 125.

Mehrabian, Albert \& Russell, James A. 1974. An approach to environmental psychology. Cambridge, London: The MIT Press.

Pallasmaa, Juhani. 2014. Space, place, and atmosphere. Emotion and peripherical perception in architectural experience. Lebenswelt. Aesthetics and Philosophy of Experience. vol. 4, p. 230-245.

Petermans, Ann; Janssens, Wim \& van Cleempoel, Koenraad. 2013. A holistic framework for conceptualizing customer experiences in retail environments. International Journal of Design. vol. $7, \mathrm{n}^{\circ} 2$, p. 1-18.

Philippopoulos-Mihalopoulos, Andreas. 2013. Atmospheres of law: Senses, affects, lawscapes. Emotion, Space and Society. vol. 7, p. 35-44.

Rappe, Guido. 2005. Interkulturelle Ethik, Bd. II: Ethische Anthropologie, 1. Teil: Der Leib als Fundament von Ethik. Berlin, Bochum, London, Paris: Europäischer Universitätsverlag.

Rauh, Andreas. 2014. On the ethical-aesthetic potentials of special atmospheres. Lebenswelt. Aesthetics and Philosophy of Experience. vol. 4, p. 246-263.

Rayburn, Steven W. \& Voss, Kevin E. 2013. A model of consumer's retail atmosphere perceptions. Journal of Retailing and Consumer Services. vol. 20, $\mathrm{n}^{\circ}$ 4, p. 400-407.

Reckwitz, Andreas. 2002. Toward a theory of social practices. A development in culturalist theorizing. European Journal of Social Theory. vol. 5, n 2, p. 243-263. 
Russell, James A. 1979. Affective space is bipolar. Journal of Personality and Social Psychology. vol. 37, $\mathrm{n}^{\circ} 3$, p. 345-356.

Russell, James A. \& Mehrabian, Albert. 1977. Evidence for a three factor theory of emotions. Journal of Research in Personality. vol. 11, n 3, p. 273-294.

Scherm, Ewald \& Julmi, Christian. 2012. Einfluss der Atmosphäre ... und wie diese auf die Entwicklung der Organisationskultur wirkt. OrganisationsEntwicklung. vol. 31, n² 2, p. 69-76.

Schmitz, Hermann. 1969. System der Philosophie, Bd. III: Der Raum, 2. Teil: Der Gefühlsraum. Bonn: Bouvier Verlag.

Schmitz, Hermann. 1974. Das leibliche Befinden und die Gefühle. Zeitschrift für philosophische Forschung. vol. 28, $\mathrm{n}^{\circ} 3$, p. 325-338.

Schmitz, Hermann. 1977. System der Philosophie, Bd. III: Der Raum, 4. Teil: Das Göttliche und der Raum. Bonn: Bouvier Verlag.

Schmitz, Hermann. 1978. System der Philosophie, Bd. III: Der Raum, 5. Teil: Die Wahrnehmung. Bonn: Bouvier Verlag.

Schmitz, Hermann. 1992 [1989]. Leib und Gefühl: Materialien zu einer philosophischen Therapeutik. $2^{\mathrm{e}}$ édition. Paderborn: Junfermann Verlag.

Schmitz, Hermann. 2009. Kurze Einführung in die Neue Phänomenologie. München: Karl Alber.

Schmitz, Hermann. 2011. Der Leib. Berlin, Boston: De Gruyter.

Schmitz, Hermann. 2014. Atmosphären. Freiburg, München: Karl Alber.

Schmitz, Hermann. 2015. Selbst sein. Über Identität, Subjektivität und Personalität. Freiburg, München: Karl Alber.

Schmitz, Hermann. 2016. Atmospheric Spaces. Ambiances. [en ligne]. Disponible sur http:// ambiances.revues.org/163.

Schmitz, Hermann; Müllan, Rudolf O. \& Slaby, Jan. 2011. Emotions outside the box - the new phenomenology of feeling and corporeality. Phenomenology and the Cognitive Sciences. vol. $10, \mathrm{n}^{\circ} 2$, p. 241-259.

Schouten, Sabine. 2007. Sinnliches Spüren. Wahrnehmung und Erzeugung von Atmosphären im Theater. Berlin: Verlag Theater der Zeit.

Sharma, Arun \& Stafford, Thomas F. 2000. The effect of retail atmospherics on customers' perceptions of salespeople and customer persuasion: An empirical investigation. Journal of Business Research. vol. 49, n², p. 183-191.

Slaby, Jan. 2014. Emotions and the extended mind. In: Christian von Scheve \& Mikko Salmela (eds.). Collective emotions. Oxford: Oxford University Press, p. 32-46.

Sørensen, Tim F. 2015. More than a feeling: Towards an archaeology of atmosphere. Emotion, Space and Society. vol. 15, p. 64-73.

Spangenberg, Eric R.; Grohmann, Bianca \& Sprott, David E. 2005. It's beginning to smell (and sound) a lot like Christmas. The interactive effects of ambient scent and music in a retail setting. Journal of Business Research. vol. 58, n 11, p. 1583-1589.

Spence, Charles. 2011. Crossmodal correspondences: A tutorial review. Attention, Perception \& Psychophysics. vol. 73, n 4, p. 971-995. 
Spence, Charles; Puccinelli, Nancy M.; Grewal, Dhruv \& Roggeveen, Anne L. 2014. Store atmospherics: A multisensory perspective. Psychology and Marketing. vol. 31, n 7, p. 472-488.

Strati, Antonio. 1999. Organization and aesthetics. London, Thousand Oaks, New Delhi: SAGE Publications.

Tombs, Alastair \& McColl-Kennedy, Janet R. 2003. Social-servicescape conceptual model. Marketing Theory. vol. 3, $\mathrm{n}^{\circ}$ 4, p. 447-475.

Turley, L. W. \& Milliman, Ronald E. 2000. Atmospheric effects on shopping behavior: A review of the experimental evidence. Journal of Business Research. vol. 49, n², p. 193-211.

Vilnai-Yavetz, Iris; Rafaeli, Anat \& Schneider-Yaacov, Caryn. 2005. Instrumentality, aesthetics and symbolism of office design. Environment and Behavior. vol. 37, $\mathrm{n}^{\circ}$ 4, p. 533-551.

Woodworth, Robert S. \& Marquis, Donald G. 1947 [1908]. Psychology. $5^{\mathrm{e}}$ édition. New York: Henry Holt and Company.

Yalch, Richard F. \& Spangenberg, Eric R. 2000. The effects of music in a retail setting on real and perceived shopping times. Journal of Business Research. vol. 49, n² 2, p. 139-147.

Yani-de-Soriano, M. Mirella \& Foxall, Gordon R. 2006. The emotional power of place: The fall and rise of dominance in retail research. Journal of Retailing and Consumer Services. vol. 13, $\mathrm{n}^{\circ} 6$, p. 403-419.

\section{ABSTRACTS}

The study of store atmospheres and their effects on the consumer's behaviour has become a significant area of research within marketing. In this context, the aim of this article is twofold. First, it is shown that the widely accepted S-O-R model is incommensurable with the store atmosphere as the object of investigation. Second, the concept of bridging qualities from German philosopher Hermann Schmitz is introduced as a promising alternative to the study of store atmospheres avoiding the identified incommensurability. As the concepts of Schmitz have not been considered within marketing theory yet, the article breaks new ground.

L'étude sur l'atmosphère des magasins et l'effet sur le comportement des consommateurs a pris une importance croissante dans la recherche sur la gestion du marketing. Dans cette perspective, notre article obéit à deux principaux enjeux. Premièrement, il vise à montrer que le paradigme S$\mathrm{O}-\mathrm{R}$ est aussi largement accepté qu'inapproprié pour penser l'atmosphère des magasins. Deuxièmement, il veut présenter le concept développé par le philosophe allemand Hermann Schmitz comme un paradigme alternatif prometteur pour étudier les conditions atmosphériques des magasins en évitant les écueils du modèle S-O-R. Comme les concepts de Schmitz n'ont pas encore été intégrés dans la théorie du marketing, cet article propose une perspective novatrice.

\section{INDEX}

Keywords: store atmosphere, S-O-R model, kinetic qualities, synesthetic qualities, phenomenology, marketing, Hermann Schmitz

Mots-clés: atmosphère des magasins, paradigme S-O-R, qualités cinétiques, phénoménologie, marketing, Hermann Schmitz 


\section{AUTHOR}

\section{CHRISTIAN JULMI}

Dr. Christian Julmi is a researcher at the Faculty of Business Administration and Economics, University of Hagen (Germany), where he received his $\mathrm{PhD}$ on atmospheres in organisations in 2015. His research interests include organizational culture and climate, atmospheres in organizations, creativity and intuition in management and phenomenology. He is an associate member of the Atmospheric Spaces network.

christian.julmi@fernuni-hagen.de 